\title{
PEMBUATAN VULKANISAT BAN DALAM DENGAN BAHAN PENGISI ARANG AKTIF KAYU BANGKIRAI
}

(THE PREPARATION OF VULCANIZED RUBBER INNER TUBE UTILIZING ACTIVATED CARBON
OF BANGKIRAI WOOD AS FILLER)

\author{
Herminiwati ${ }^{1)}$, Purnomo Darmadji ${ }^{2)}$, Supranto ${ }^{3)}$
}

\begin{abstract}
The objective of this research was to study the preparation of vulcanized rubber inner tube for motorcycles. Activated carbon of bangkirai wood and carbon black N330 were utilized as filler either separately formulated or combination. The ratio of activated carbon and carbon black were $25 / 0$; $18,75 / 6,25 ; 12,5 / 12,5 ; 6,25 / 18,75$ and $0 / 25$ respectively. In wood processing, only about $60 \%$ of wood is converted to end product, with some of $30 \%$ of the rest is converted to organic solid waste. This organic solid waste needs to be handled or converted to some more usefull product such as carbon rubber filler. The filler was prepared by carbonization process at temperature $450^{\circ} \mathrm{C}$ for one hour and activation process with $\mathrm{NaCl} 4 \%$ for twenty four hours, followed by pyrolisis at temperature $500^{\circ} \mathrm{C}$ for one hour. Filler were milled and sieved by 400 mesh siefter. The vulcanized rubber inner tube was tested for its physical properties according to SNI 06-1542-1984. The research showed that a filler combination of activated carbon of bangkirai wood and carbon black in comparison of $6,25 / 18,75$ could meet the requirements of SNI 061542-1984 in tensile strength, elongation at break, $300 \%$ modulus, hardness, density, and $200 \%$ permanent set.
\end{abstract}

Key words : filler, activated carbon, bangkirai wood, inner tube

\section{PENDAHULUAN}

Bahan pengisi penguat yang banyak digunakan untuk pembuatan barang-barang karet adalah carbon black yang dibuat dari proses thermal cracking hidrokarbon dari minyak bumi (Ellis and Novak, 1978). Kebutuhan bahan pengisi yang berupa carbon black untuk industri ban dalam dan ban luar sebanyak 82,8 ribu ton dengan jumlah diimpor sebanyak 36,3 ribu ton atau senilai 122 milyar rupiah (BPS,1998). Nilai ini akan terus meningkat dengan perkembangan industri barang karet di Indonesia yang memerlukan tersedianya bahan pengisi secara kontinyu dengan jumlah yang makin besar. Dengan makin berkurangnya cadangan minyak bumi dunia, bahan pengisi barang karet yang diproduksi berlandaskan proses kimia thermal cracking minyak bumi akan makin mahal, sehingga perlu dicari substitusinya.

Pemecahan rantai karbon dalam minyak bumi dilakukan dengan proses thermalcracking menggunakan energi panas sebagai alat pemecah rantai hidrokarbon. Dengan mengatur temperatur dan laju pemberian energi panas, produk pemutusan rantai karbon dapat dikendalikan sampai diperoleh agregat karbon serta senyawa kimia dengan berat molekul rendah (Shreve and Brink, 1977). Selulose dalam limbah industri kayu mempunyai struktur rantai yang mirip dengan hidrokarbon dalam minyak bumi. Rantai yang panjang dalam selulose ini dimungkinkan dapat dipecah menjadi agregat karbon dan senyawa-senyawa kimia dengan berat molekul rendah. Salah satu kayu hutan Indonesia adalah kayu bangkirai dan berdasar Atlas Kayu Indonesia (1981) mempunyai komposisi kimia meliputi: selulosa $52,9 \%$, lignin $24 \%$, abu $1 \%$, dan silika $0,4 \%$. Proses thermal cracking yang dimodifikasi ini diharapkan dapat mengubah limbah industri kayu menjadi bahan pengisi penguat karet.

Menurut Morton (1987) sifat fisik dan kimia carbon black yang berpengaruh terhadap penguatan vulkanisat karet meliputi ukuran partikel, luas permukaan, struktur dan aktivitas permukaan. Ukuran partikel didefinisikan sebagai diameter rata-rata dari partikel yang membentuk agregat. Adapun luas permukaan adalah sifat yang menunjukkan seberapa besar permukaan dapat berinteraksi dengan bahan lain yang ada dalam kompon karet. Struktur merupakan

\footnotetext{
${ }^{1)}$ Balai Besar Kulit, Karet dan Plastik

2) Fakultas Teknologi Pertanian UGM

3) Jurusan kimia Fakultas Teknik UGM
} 
banyaknya partikel karbon yang terikat bersama-sama dalam agregat dengan berbagai bentuk dan ukuran, sedangkan aktivitas permukaan yaitu kemampuan bahan pengisi mengadakan ikatan dengan karet baik secara fisika maupun kimia.

\section{BAHAN DAN METODE PENELITIAN}

\section{Bahan Penelitian}

Bahan penelitian terdiri atas karet alam RSS I, carbon black N330 (ukuran partikel $31 \mathrm{~nm}$, absorpsi iodin $80,7 \mathrm{~g} / \mathrm{kg}$, arang aktif kayu bangkirai (lolos 400 mesh $\approx 30 \mu$, absorpsi iodin $110,34 \mathrm{~g} / \mathrm{kg}$ ), zink oksida, asam stearat, benzothiazyl disulphide (MBTS), tetramethyl thiuram disulphide(TMTD), naphthenic oil, trimethyl dihydro quinoline (TMQ), peptizer, paraffin wax, belerang, potongan kayu bangkirai $(2 \times 2 \times 2 \mathrm{~cm})$, garam $\mathrm{NaCl} 4 \%$.

\section{Peralatan Penelitian}

Alat penelitian terdiri atas reaktor thermal cracking, gergaji listrik, ayakan Tyler 400 mesh, mesin two roll mill (Kodaira Seisaku-sho Ltd, kap. 8-5 lbs), hidrolik press (Kodaira Seisaku-sho Ltd, curing press 30 ton), rheometer (Conical disk rheometer model 100 Toyo Seiki), alat uji tensile strength (Toyo Seiki, kap. $500 \mathrm{~kg}$ ), alat uji kekerasan (Toyo Seiki durometer A), alat uji pengusangan (Geer type oven) dan alat uji permanen set (Toyo Seiki).

\section{Cara Penelitian}

Rancangan Percobaan

Dalam penelitian ini faktor yang dipelajari meliputi pengaruh bahan pengisi kayu bangkirai dan carbon black secara sendiri maupun kombinasi untuk pembuatan vulkanisat ban dalam kendaraan bermotor.
Adapun variasi perbandingan arang aktif (AA) dan carbon black (CB) berturut-turut adalah : 25/0; $18,75 / 6,25 ; 12,5 / 12,5 ; 6,25 / 18,75$ dan $0 / 25$

Perlakuan dan analisis dibuat tiga ulangan sedangkan parameter yang diamati meliputi : tegangan putus, perpanjangan putus, modulus $300 \%$, ketahanan sobek, kekerasan, perpanjangan tetap $200 \%$ dan ketahanan terhadap pengusangan.

\section{Pembuatan filler}

Pembuatan filler kayu bangkirai dilakukan melalui tahap seperti diagram pada Gambar 1.

- Proses karbonisasi atau pirolisis, dilakukan dalam reaktor pirolisa pada suhu $450^{\circ} \mathrm{C}$ selama 1 jam. Pirolisis merupakan proses peruraian kayu dengan udara terbatas atau tanpa udara dan hasilnya adalah arang. Arang merupakan residu pembakaran yang sebagian besar komponennya berupa karbon.

- Proses aktivasi, dilakukan dengan menggunakan aktivator $\mathrm{NaCl} 4 \%$ selama 1 jam, kemudian arang dicuci dengan air dan dilanjutkan dengan pirolisis pada suhu $500^{\circ} \mathrm{C}$ selama $1 \mathrm{jam}$. Proses ini dimaksudkan untuk memperluas permukaan arang aktif dengan cara menghilangkan ter yang masih melekat pada permukaan dan pori-pori arang. Selanjutnya arang aktif digiling dan diayak dengan ayakan 400 mesh. Arang aktif yang dihasilkan diuji terhadap luas permukaan (absorpsi iodin).

\section{Pembuatan kompon dan vulkanisat}

1. Formulasi kompon sebagai berikut : karet alam 100 phr, peptizer $0,15 \mathrm{phr}$, zink oksida $4 \mathrm{phr}$, asam stearat $2 \mathrm{phr}$, naphthenic oil $6 \mathrm{phr}$, paraffin wax 1,2 phr, TMQ 1,5 phr, MBTS 0,8 phr, TMTD 0,2 phr dan belerang 1,2 phr sedangkan bahan pengisi arang aktif dan carbon black $\mathrm{N} 330$ divariasi $(\mathrm{phr}=$ per hundred rubber)

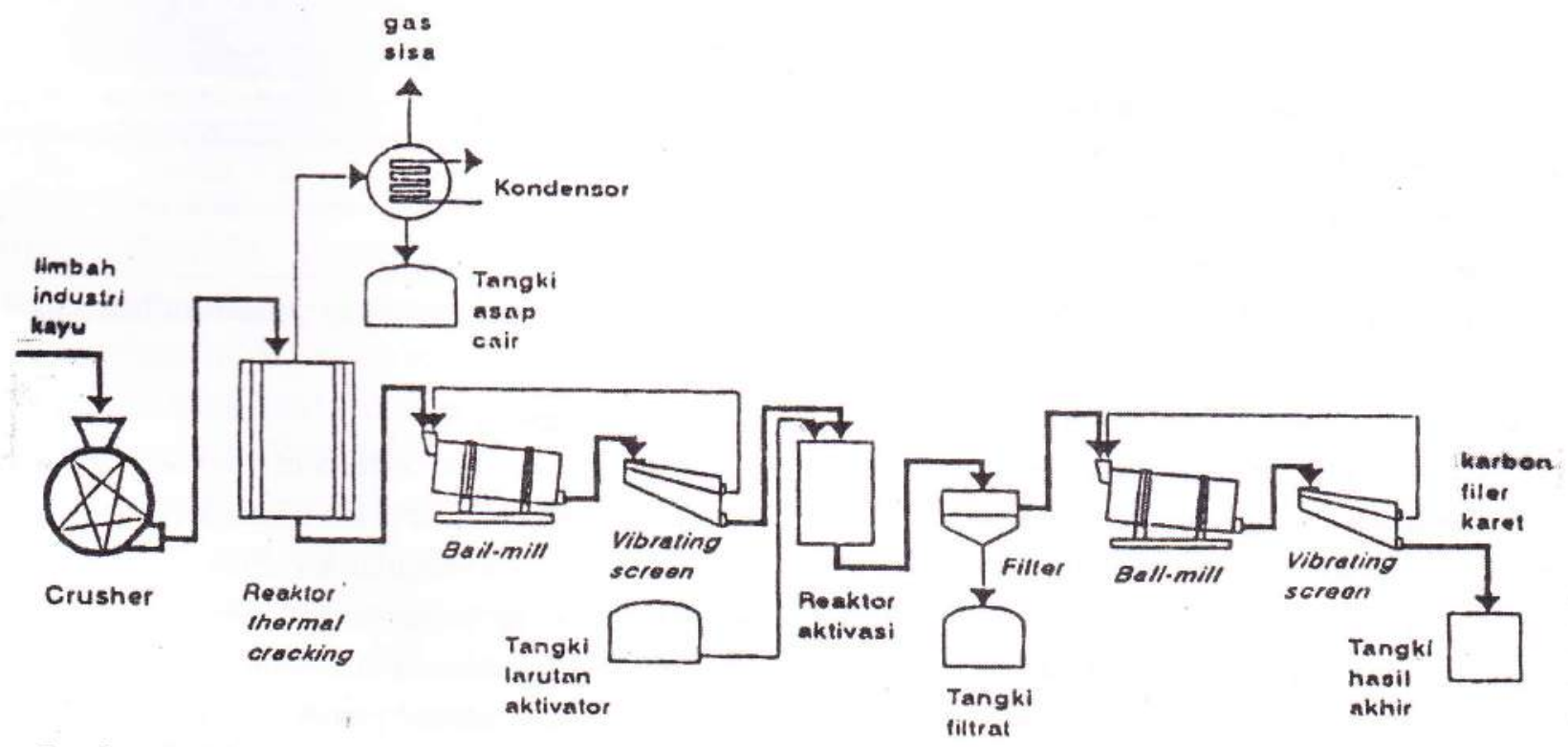

Gambar 1. Diagram alir proses pembuatan bahan pengisi karet dari limbah industri kayu dengan proses kimia thermal cracking 
2. Proses pembuatan kompon dilakukan dengan mesin two roll mill. Karet terlebih dahulu digiling sampai plastis (dimastikasi) selama kurang lebih 2 menit. Peptizer dimasukkan dan digiling kemudian zink oksida, asam stearat, dan antidegradan TMQ. Bahan pengisi dan naphthenic oil ditambahkan secara bergantian sambil terus digiling sampai kedua bahan tersebut tercampur homogen. Paraffin wax, akselerator MBTS dan TMTD dimasukkan serta digiling sampai homogen dan terakhir belerang dimasukkan.

\section{Pengujian}

Vulkanisat karet pada berbagai variasi bahan pengisi diuji dalam aplikasinya untuk ban dalam kendaraan bermotor sesuai cara uji SNI. 06-1542-1989 Kompon Ban Dalam Kendaraan Bermotor.

\section{HASIL DAN PEMBAHASAN}

Hasil uji sifat fisik vulkanisat ban dalam dapat dilihat pada gambar berikut :

\section{Tegangan putus (tensile strength)}

Hasil uji tegangan putus vulkanisat ban dalam dengan berbagai variasi bahan pengisi disajikan pada Gambar 2. Berdasarkan data tersebut terlihat bahwa penggunaan bahan pengisi arang aktif kayu bangkirai maupun carbon black mempengaruhi sifat tegangan putus. Makin banyak proporsi arang aktif maka tegangan putus cenderung turun, sebaliknya makin besar penambahan carbon black, tegangan putus makin meningkat. Carbon black merupakan bahan pengisi penguat (reinforcing filler) sehingga penambahannya dalam kompon karet akan meningkatkan sifat tegangan putus, ketahanan sobek, ketahanan kikis dan kekerasan (Hoffmann, 1989).

Menurut Morton (1987), sifat fisik dan kimia yang berpengaruh terhadap penguatan vulkanisat karet adalah ukuran partikel, luas permukaan, struktur, dan aktivitas permukaan. Ukuran partikel carbon black lebih kecil dibanding arang aktif kayu bangkirai. Partikel kasar (> 325 mesh) menurunkan tegangan putus dan ketahanan sobek (Dannenberg 1980).

Makin kecil ukuran partikel memungkinkan bahan pengisi terdispersi dengan baik dan merata dalam kompon karet. Akibatnya terjadi interaksi secara fisika dan kimia dengan lebih baik pula. Secara fisika terjadi adsorpsi antara bahan pengisi dengan karet melalui tenaga Van der Waal's. Secara kimia terbentuk ikatan antara karet dengan gugus fungsional pada permukaan karbon. Karet alam terdiri dari unit monomer isoprena (C5H8) dengan satu ikatan rangkap tiap monomernya. Adanya ikatan rangkap dan gugus $\mathrm{C}_{1} \alpha$ metilen merupakan gugus reaktif untuk terjadinya ikatan kimia. Terbentuknya ikatan-ikatan mengakibatkan vulkanisat menjadi kaku dan kuat sehingga tegangan putusnya tinggi.

Bahan pengisi arang aktif kayu bangkirai mempunyai nilai tegangan putus lebih kecil dibanding carbon black, karena selain partikelnya jauh lebih besar, kemungkinan juga hilangnya gugus-gugus fungsional pada permukaan karbon pada proses aktivasi dan pirolisis. Akibatnya aktivitas permukaan rendah dan ikatan yang terbentuk kurang. Meskipun arang aktif kayu bangkirai memberikan nilai tegangan putus lebih rendah dibanding carbon black, namun penambahannya dalam kompon karet sebesar 6,25 phr ( $25 \%$ dari jumlah bahan pengisi) dan $12,5 \mathrm{phr}$ ( $50 \%$ dari jumlah bahan pengisi) memberikan nilai tegangan putus sebesar $15,53 \mathrm{~N} / \mathrm{mm}^{2}$ dan $16,82 \mathrm{~N} / \mathrm{mm}^{2}$. Nilai tersebut memenuhi persyaratan SNI 06-1542-1984: Kompon ban dalam untuk kendaraan bermotor yang menetapkan persyaratan untuk tegangan putus minimum $15 \mathrm{~N} / \mathrm{mm} 2$.

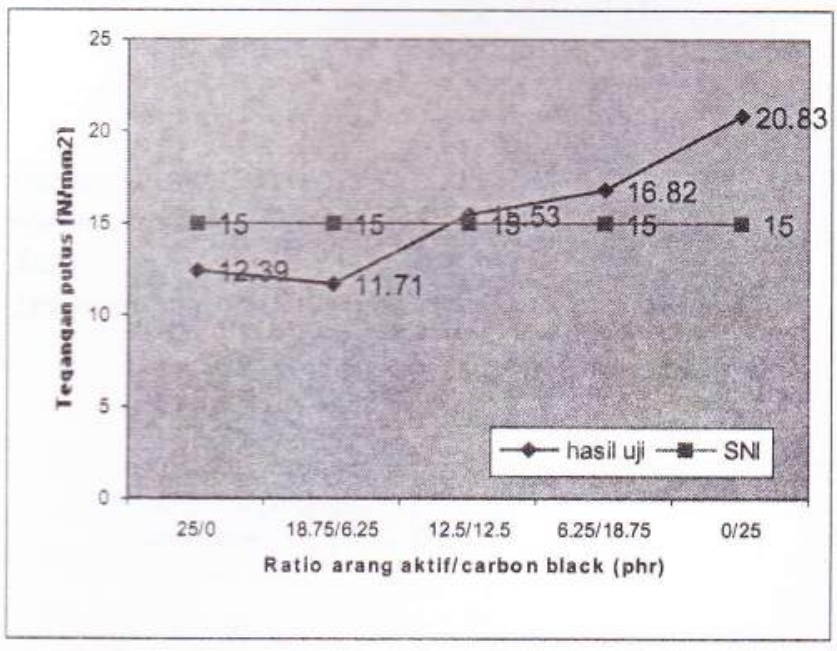

Gambar 2. Tegangan putus vulkanisat ban dalam

\section{Perpanjangan putus}

Pada gambar 3 terlihat bahwa penggunaan bahan pengisi arang aktif kayu bangkirai dan carbon black secara sendiri maupun kombinasi sebesar $25 \mathrm{phr}$ memberikan nilai perpanjangan putus yang baik dan memenuhi persyaratan SNI. Dalam SNI 06-1542-1984 ditetapkan persyaratan perpanjangan putus sebesar minimum $500 \%$. 
Dalam pembuatan kompon ban dalam untuk kendaraan bermotor diperlukan penambahan bahan pengisi penguat guna meningkatkan sifat fisik dan mekanik, sehingga sesuai dengan persyaratan dan penggunaannya.

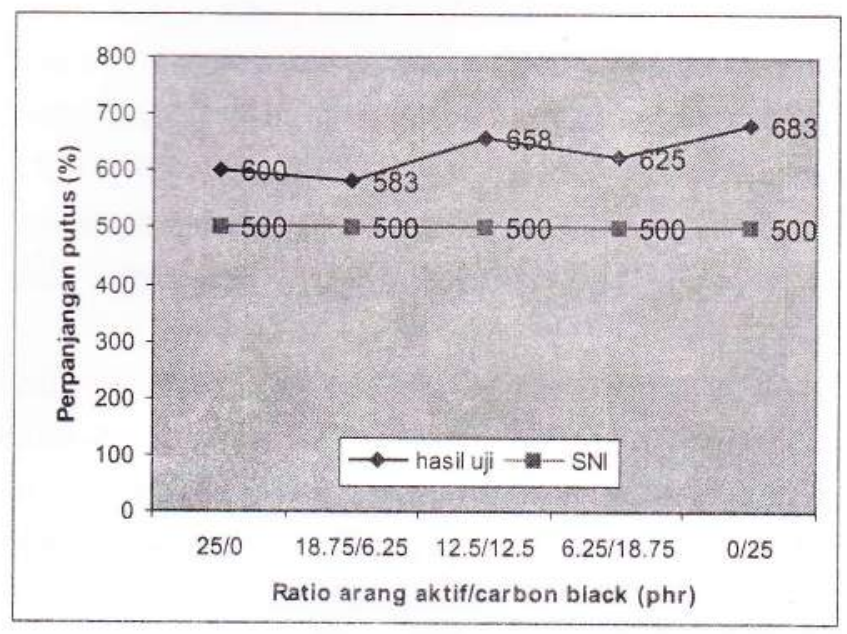

Gambar 3. Perpanjangan putus vulkanisat ban dalam

Nilai perpanjangan putus dipengaruhi oleh beberapa hal, yaitu:

a. Banyaknya bahan pengisi yang ditambahkan dalam kompon karet.

Makin banyak bahan pengisi yang ditambahkan, perpanjangan putus turun. Penambahan bahan pengisi yang besar menyebabkan terjadinya aglomerasi agregat karena jenuhnya molekul karet sehingga tidak semua bahan pengisi terikat. Akibatnya vulkanisat mudah putus apabila ditarik.

b. Banyaknya ikatan yang terbentuk

Makin banyak terbentuk ikatan antara gugus fungsional dari bahan pengisi dengan molekul karet maka akan mengurangi keleluasaan gerak rantai polimer sehingga elastisitas (perpanjangan putus) turun. Selain itu struktur bahan pengisi juga berpengaruh terhadap perpanjangan putus. Makin tinggi struktur makin banyak ruang kosong yang dapat dimasuki molekul karet sehingga gerak rantai polimer terhambat dan mengakibatkan turunnya elastisitas.

Penggunaan bahan pengisi arang aktif kayu bangkirai, carbon black atau kombinasinya sebesar $25 \mathrm{phr}$ memberikan nilai perpanjangan putus yang baik dan memenuhi persyaratan SNI. Ini berarti bahwa penambahan bahan pengisi tersebut tidak menyebabkan terjadinya aglomerasi agregat maupun peningkatan viskositas kompon yang tinggi sehingga vulkanisat menjadi kaku dan keras.

\section{Modulus $300 \%$}

Hasil uji modulus $300 \%$ dari vulkanisat ban dalam seperti terlihat pada Gambar 4. Modulus $300 \%$ adalah besarnya beban yang diperlukan untuk menarik vulkanisat pada perpanjangan $300 \%$.

Gambar 4 menunjukkan bahwa bahan pengisi arang aktif kayu bangkirai dan carbon black mempengaruhi modulus $300 \%$. Makin besar proporsi carbon black maka modulus makin naik, sebaliknya makin banyak proporsi arang aktif modulus turun.

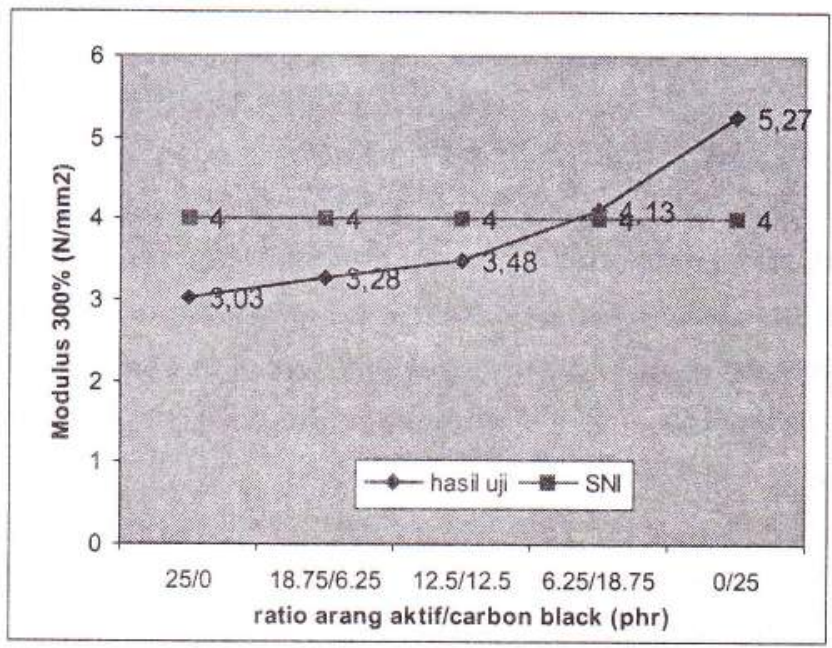

Gambar 4. Modulus 300\% vulkanisat ban dalam

Menurut Franta (1989) modulus akan naik dengan peningkatan jumlah bahan pengisi dalam kompon karet, meskipun kenaikannya tidak linier. Selain itu disebutkan juga bahwa modulus dipengaruhi oleh struktur dan aktivitas permukaan bahan pengisi. Struktur menunjukkan banyaknya partikel karbon yang berfusi membentuk agregat. Makin tinggi struktur akan menaikkan viskositas kompon, sehingga meningkatkan sifat fisis dan mekanis barang karet (Patel and Brown, 1985)

Aktivitas permukaan bahan pengisi berperan dalam efek penguatan karena adanya interaksi antara bahan pengisi dengan karet, yang terjadi secara fisika maupun kimia. Interaksi dipengaruhi oleh tenaga interaksi yang berupa gaya Van der Wall's maupun adanya gugus-gugus fungsional pada permukaan bahan pengisi seperti gugus fenolat, hidrogen reaktif, lakton, kuinon, hidroksil dan karboksil. 
Ditinjau dari struktur, maka carbon black N330 mempunyai struktur yang lebih tinggi dibanding arang aktif kayu bangkirai sehingga mempunyai cukup banyak ruang kosong yang dapat dimasuki molekul karet. Pada proses pencampuran, molekul karet mengisi semua ruang kosong pada agregat carbon black sehingga terjadi adsorpsi molekul karet pada carbon black dan menyebabkan naiknya viscositas kompon. Kompon menjadi kaku dan kuat sehingga modulus meningkat.

Ditinjau dari aktivitas permukaan maka bahan pengisi arang aktif kayu bangkirai mempunyai aktivitas permukaan lebih kecil dibanding carbon black. Gugus-gugus fungsional pada permukaan arang aktif kemungkinan hilang pada proses aktivasi dan pirolisis.

Oleh karena itu formulasi dengan proporsi carbon black lebih banyak, yakni pada ratio arang aktif dan carbon black sebesar 6,25/18,75 dan 0/25 memberikan nilai modulus lebih tinggi sebesar 4,13 $\mathrm{N} / \mathrm{mm}^{2}$ dan $5,27 \mathrm{~N} / \mathrm{mm}^{2}$. Nilai tersebut memenuhi persyaratan SNI untuk modulus 300\% sebesar minimum $4 \mathrm{~N} / \mathrm{mm}^{2}$.

\section{Kekuatan sobek}

Hasil uji kekuatan sobek vulkanisat ban dalam seperti terlihat pada Gambar 5. Nilai kekuatan sobek cenderung meningkat dengan peningkatan jumlah carbon black dalam kompon karet. Namun demikian untuk semua formulasi dengan ratio perbandingan arang aktif kayu bangkirai dan carbon black sebesar $25 / 0 ; 18,75 / 6,25 ; 12,5 / 12,5 ; 6,25 / 18,75$ dan $0 / 25$ memberikan nilai kekuatan sobek rendah sebesar 2,49 $\mathrm{N} / \mathrm{mm}^{2}-5,08 \mathrm{~N} / \mathrm{mm}^{2}$. Nilai tersebut masih dibawah persyaratan SNI yang menetapkan persyaratkan untuk kekuatan sobek minimum $7,5 \mathrm{~N} / \mathrm{mm}^{2}$.

Franta (1989) mengemukakan bahwa kekuatan sobek akan meningkat dengan peningkatan luas permukaan (surface area) bahan pengisi. Ditinjau dari luas permukaan yang diukur dengan angka absorpsi iodin, maka arang aktif kayu bangkirai mempunyai angka absorpsi iodin $110,34 \mathrm{~g} / \mathrm{kg}$ dan angka ini lebih besar daripada angka absorpsi iodin carbon black sebesar $80,7 \mathrm{~g} / \mathrm{kg}$.

Meskipun luas permukaan bahan pengisi arang aktif kayu bangkirai lebih besar karena lebih porous dan mempunyai permukaan dalam (internal surface) lebih luas dibanding carbon black, akan tetapi kemungkinan hanya sedikit mengandung gugus fungsional yang dapat berikatan dengan karet. Akibatnya kekuatan sobek vulkanisat rendah. Selain itu arang aktif mempunyai ukuran partikel jauh lebih besar $(30 \mu \mathrm{m})$ dibanding carbon black N330 (31 nm). Menurut Bonstra dan Medalia (1963) penambahan butiran karbon yang mempunyai diameter $16 \mu \mathrm{m}-67$ $\mu \mathrm{m}$ meningkatkan keretakan dan penurunan tegangan putus, ketahanan sobek, ketahanan retak lentur dan ketahanan kikis.

Penggunaan bahan pengisi carbon black secara sendiri sebesar 25 phr, ketahanan sobeknya juga belum maksimal. Menurut Byers (1987) penggunaan carbon black seri N300 akan memberikan ketahanan sobek maksimal pada penambahan sebesar 35-50 phr.

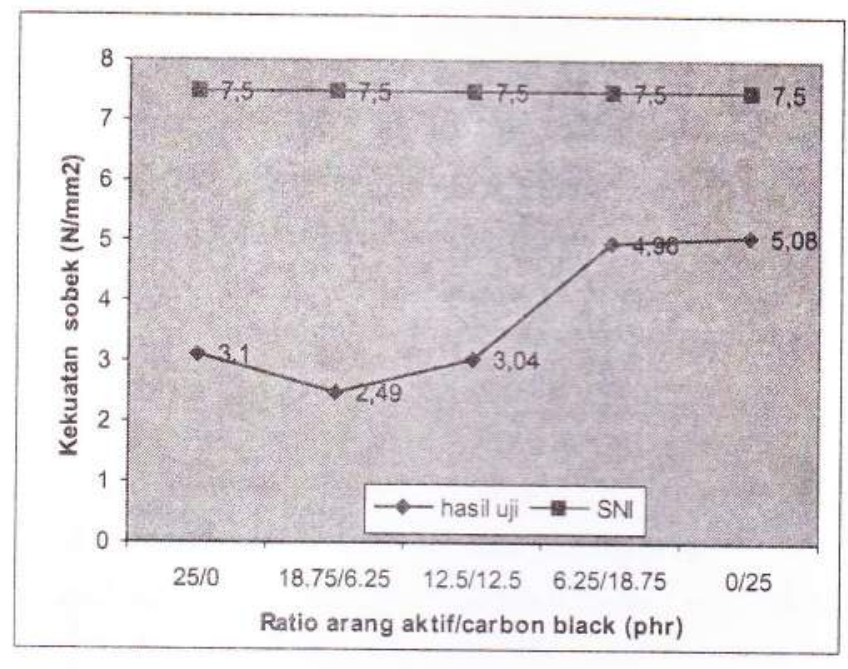

Gambar 5. Kekuatan sobek vulkanisat ban dalam

\section{Kekerasan}

Kekerasan vulkanisat ban dalam pada berbagai ratio bahan pengisi arang aktif kayu bangkirai dan carbon black seperti terlihat pada Gambar 6 . Gambar 6 menunjukkan bahwa kekerasan dipengaruhi oleh bahan pengisi arang aktif kayu bangkirai maupun carbon black. Kekerasan vulkanisat karet untuk semua formulasi dengan ratio perbandingan bahan pengisi arang aktif dan carbon black berturut-turut sebesar $25 / 0 ; 18,75 / 6,25 ; 12,5 / 12,5 ; 6,25 / 18,75$ dan $0 / 25$ memberikan nilai kekerasan sebesar 48 shore A-54 shore A. Ini menunjukkan bahwa semua formulasi memberikan kekerasan yang baik dan memenuhi syarat SNI. Berdasar SNI 06-1542-1984 persyaratan 
kekerasan adalah sebesar 45 shore A- 55 shore A.

Nilai kekerasan dipengaruhi oleh banyaknya bahan pengisi, ukuran partikel dan struktur (Franta, 1989). Jumlah bahan pengisi yang digunakan dalam pembuatan vulkanisat ban dalam untuk semua formulasi adalah 25 phr. Adapun ditinjau dari ukuran partikel dan struktur, maka carbon black mempunyai ukuran partikel lebih kecil dan struktur lebih tinggi. Akibatnya interaksi carbon black dengan molekul karet lebih baik sehingga kompon lebih kaku dan keras. Oleh karena itu formulasi dengan bahan pengisi carbon black secara sendiri sebesar 25 phr mempunyai nilai kekerasan tinggi sebesar 54 shore $\mathrm{A}$.

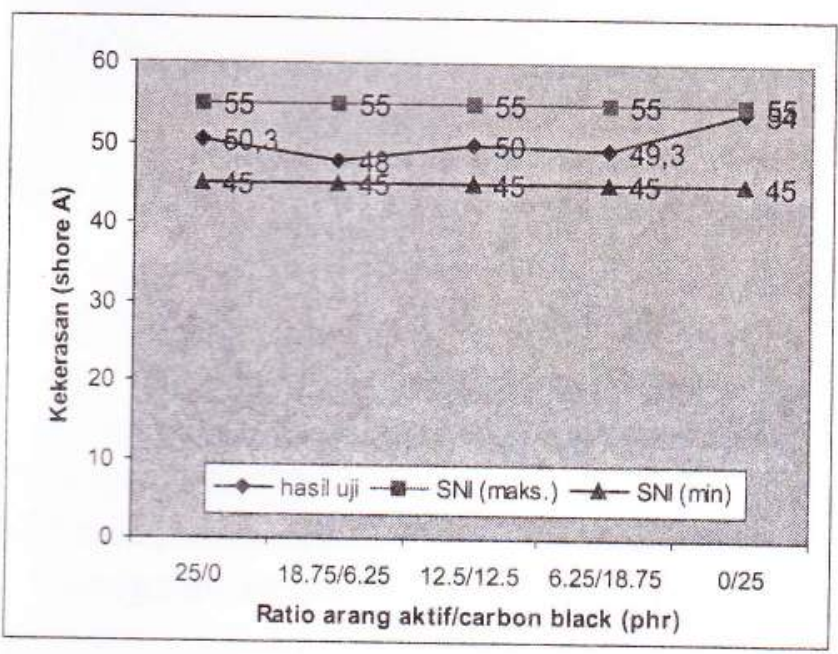

Gambar 6. Kekerasan vulkanisat ban dalam

\section{Bobot jenis}

Berdasarkan hasil uji bobot jenis (Gambar 7) terlihat bahwa penggunaan bahan pengisi arang aktif kayu bangkirai dan carbon black mempengaruhi bobot jenis vulkanisat ban dalam.

Gambar 7 menunjukkan bahwa semua formulasi yang diteliti dapat memenuhi syarat SNI 061542-1984, yang menetapkan persyaratan bobot jenis sebesar $1 \mathrm{~g} / \mathrm{cm}^{3}-1,25 \mathrm{~g} / \mathrm{cm}^{3}$. Vulkanisat dengan bahan pengisi arang aktif kayu bangkirai secara sendiri sebesar 25 phr mempunyai nilai bobot jenis sebesar 1,07 $\mathrm{g} / \mathrm{cm}^{3}$, sedangkan carbon black mempunyai bobot jenis sebesar $1,25 \mathrm{~g} / \mathrm{cm}^{3}$. Hal tersebut disebabkan karena arang aktif kayu bangkirai lebih porous dan mempunyai permukaan dalam (internal surface) lebih besar, sebagai akibat proses aktivasi dan pirolisis. Oleh karena itu bobot jenis makin turun dengan peningkatan proporsi bahan pengisi arang aktif dalam kompon.

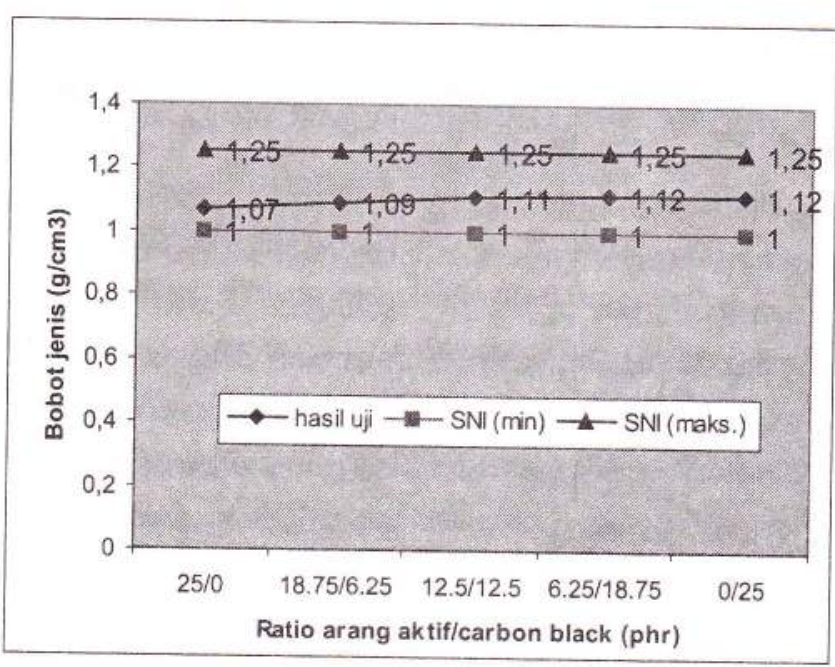

Gambar 7. Bobot jenis vulkanisat ban dalam

\section{Perpanjangan tetap $200 \%$}

Perpanjangan tetap (permanen set) menunjukkan kemampuan vulkanisat karet untuk kembali kebentuk semula setelah dilakukan penarikan pada panjang dan waktu tertentu. Makin kecil perpanjangan tetap vulkanisat makin baik, karena deformasi permanen makin kecil. Deformasi permanen terjadi setelah vulkanisat ditarik pada perpanjangan $200 \%$ selama 24 jam.

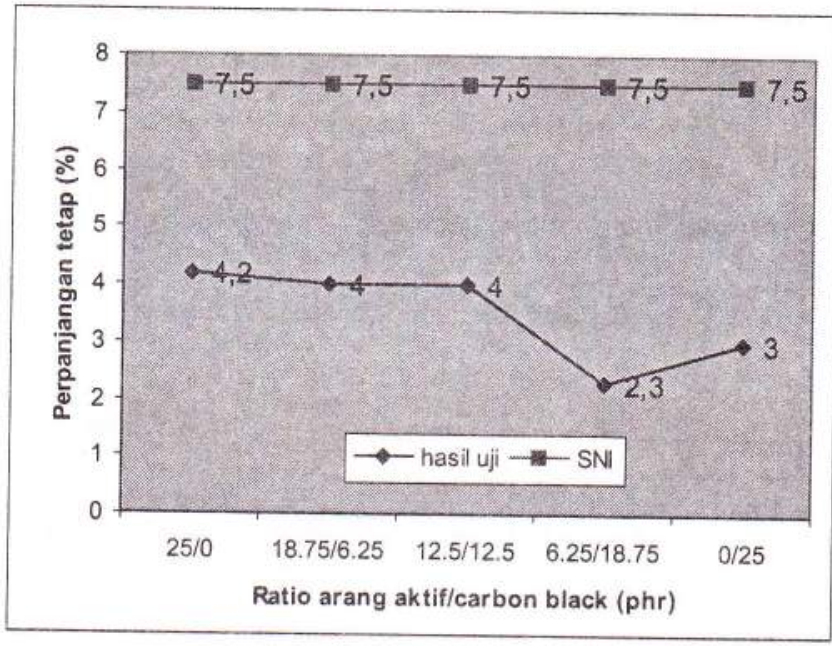

Gambar 8. Perpanjangan tetap 200\% vulkanisat ban dalam

Gambar 8 menunjukkan hasil uji perpanjangan tetap vulkanisat ban dalam dengan berbagai ratio bahan pengisi arang aktif kayu bangkirai dan carbon black. Berdasar data hasil uji tersebut nampak bahwa semua formulasi yang diteliti dapat memenuhi SNI. Persyaratan perpanjangan tetap menurut SNI 06-1542- 
1984 sebesar maksimum 7,5\%. Ini menunjukkan bahwa vulkanisat ban dalam yang diteliti mempunyai deformasi permanen relatifkecil.

Nilai perpanjangan tetap dipengaruhi oleh ukuran partikel dan banyaknya bahan pengisi dalam kompon karet (Franta, 1989). Penggunaan bahan pengisi sebesar 25 phr untuk semua formulasi dengan berbagai variasi komposisi arang aktif dan carbon black masih memberikan sifat elastis yang baik pada vulkanisat sehingga apabila dilakukan penarikan mudah kembali ke bentuk semula.

\section{Pengusangan (aging)}

Pengusangan mengakibatkan turunnya sifat fisik barang karet seperti tegangan putus, perpanjangan putus, ketahanan sobek, dan fatique resistance selama masa penyimpanan dan pemakaian. Karet menjadi keras dan retak, lunak dan lekat-lekat. Penurunan sifat fisik disebabkan terjadinya degradasi karet karena oksidasi oleh oksigen dan ozon. Oksidasi dipercepat dengan adanya panas, sinar ultraviolet, lembab dan logam-logam yang mengkatalisa oksidasi. Hasil uji tegangan putus dan perpanjangan putus setelah pengusangan seperti terlihat pada Gambar 9 dan Gambar 10 .

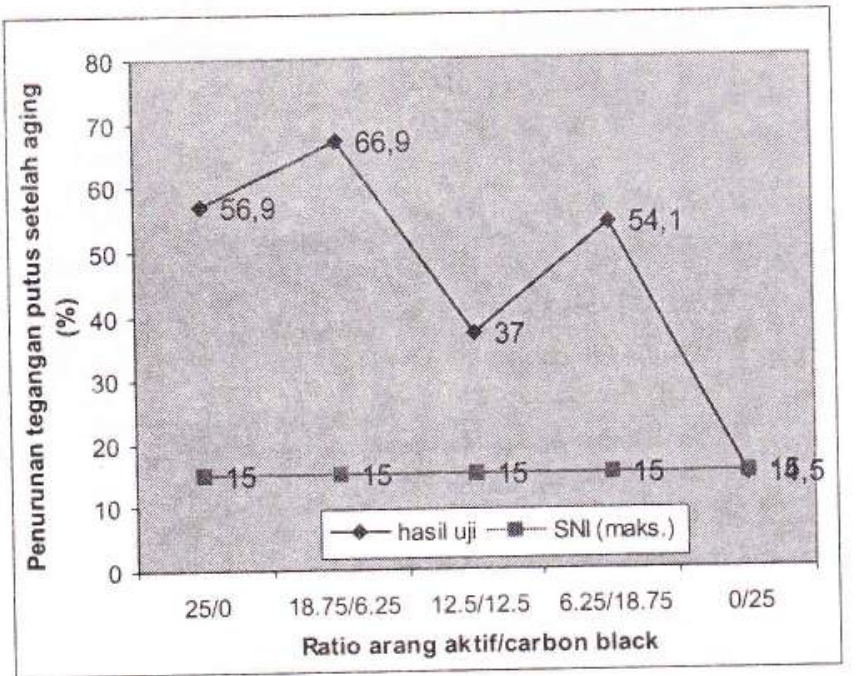

Gambar 9. Penurunan tegangan putus vulkanisat ban dalam setelah pengusangan

Pada Gambar 9 nampak bahwa penambahan bahan pengisi arang aktif kayu bangkirai dan carbon black mempengaruhi sifat tegangan putus setelah pengusangan. Penambahan bahan pengisi arang aktif on karet menurunkan tegangan putus relatif tinggi sebesar 37\%-66,9\%, sehingga belum dapat memenuhi persyaratan SNI. Penggunaan bahan pengisi carbon black secara sendiri sebesar 25 phr memberikan nilai penurunan tegangan putus relatif baik sebesar 14,5\% dan memenuhi persyaratan SNI. Menurut SNI 061542-1984 persyaratan penurunan tegangan putus setelah pengusangan maksimum $15 \%$.

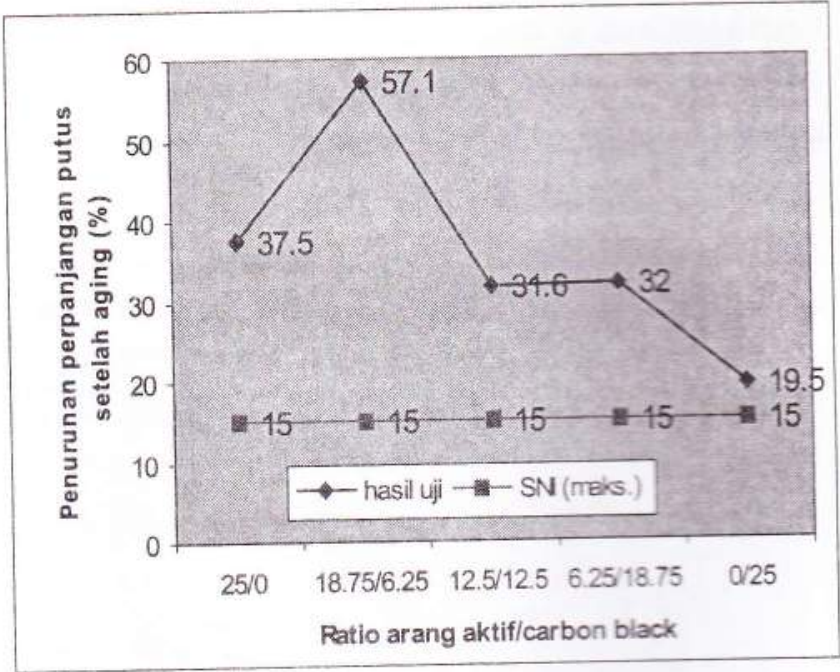

Gambar 10. Penurunan perpanjangan putus vulkanisat ban dalam setelah pengusangan

Pada gambar 10 terlihat bahwa penurunan perpanjangan putus setelah pengusangan dipengaruhi oleh penggunaan bahan pengisi arang aktif kayu bangkirai dan carbon black. Makin banyak proporsi arang aktif dalam kompon karet, penurunan perpanjangan putus cenderung makin tinggi. Penurunan perpanjangan putus dengan bahan pengisi carbon black secara sendiri sebanyak 25 phr lebih kecil dibanding arang aktif, namun penurunannya sebesar $19,5 \%$ belum memenuhi syarat SNI. Persyaratan SNI 06-1542-1984 menetapkan penurunan perpanjangan putus setelah pengusangan sebesar maksimum $15 \%$.

Menurut Eirich (1978) faktor yang dapat meningkatkan ketahanan terhadap pengusangan diantaranya adalah pemilihan dan pemberian antidegradan. Penggunaan N-isopropyl-N'-phenyl-pphenylendiamine (IPPD) akan memberikan aktivitas antioksidan, anti flex fatique dan antiozonan yang 
sangat baik. Disebutkan juga bahwa carbon black merupakan penyerap sinar ultraviolet terbaik dan dapat berinteraksi dengan antidegradan sehingga meningkatkan ketahanannya terhadap pengusangan. Oleh karena itu sesuai dengan Eirich (1978), terlihat bahwa formulasi kompon dengan carbon black mempunyai nilai penurunan tegangan putus dan perpanjangan putus lebih kecil dibanding arang aktif. Formulasi kompon ban dalam (Bayer, 1967) yang diteliti menggunakan antioksidan trimetil dihidro quinolin (TMQ). TMQ tergolong mempunyai aktivitas antioksidan, antiozonan dan anti flex fatigue cukup (Eirich,1978). Untuk meningkatkan ketahanan terhadap pengusangan perlu digunakan antioksidan yang sesuai dan aktivitasnya tinggi.

\section{KESIMPULAN}

1. Arang aktif kayu bangkirai dapat digunakan sebagai bahan pengisi vulkanisat ban dalam untuk kendaraan bermotor.

2. Vulkanisat ban dalam yang dibuat dengan proporsi bahan pengisi arang aktif kayu bangkirai dan carbon black dengan perbandingan arang aktif dan carbon black sebesar 6,25/18,75 mempunyai sifat fisis yang memenuhi persyaratan SNI dalam hal tegangan putus, perpanjangan putus, modulus $300 \%$, kekerasan, bobot jenis, dan perpanjangan tetap 200 $\%$.

3. Arang aktif kayu bangkirai mempunyai potensi untuk mensubstitusi carbon black, tetapi belum bisa menyamai.

4. Pemanfaatan limbah kayu bangkirai sebagai arang aktif untuk bahan pengisi barang karet dapat mengurangi bahan pengisi impor sekaligus mengatasi masalah lingkungan.

\section{DAFTAR PUSTAKA}

Anonim, 1981. Atlas Kayu Indonesia. Jilid 1. Balai Penelitian Hasil Hutan, Bogor.

Bayer, 1967. Formulary for The Rubber Industry,
Rubber Chemicals Division, Bombay.

Bonstra, B.B., and A.I. Medalia, 1963. Journal of Rubber Age. 92(6), 892 (1963); 93 (1), 82 (1963).

BPS, 1998. Statistik Perdagangan Luar Negeri Indonesia, Impor. Biro Pusat Statistik, Jakarta.

Byers, J.T., 1987. Filler Part I: Carbon black dalam Maurice Morton, ed., Rubber Technology. Van Nostrand Reinhold. New York.

Cheremisinoff, P.N., 1978. Carbon Adsorption Hand Book. Ann Arbor Science Publisher, Ann Arbor Michigan.

Dannenberg, E.M., 1980. Journal of Rubber Chemistry and Technology, Vol. 55, p.861-868. The Rubber Division American Chemical Society, Inc. USA.

Eirich, F.R. (Ed).1978. Science and Technology of Rubber. Academic Press Inc. USA.

Ellis, K.W, and Z.T. Novak, 1978. Modern Carbon Black dalam Proceeding Natural Rubber Technologi Seminar. 4-5 Desember, p.95-110.

Franta., I, 1989. Elastomers and Rubber Compounding Materials, Manufacture, Properties and Application. Elvevier, Amsterdam, Oxford, New York.

Hofmann, W.,1989. Rubber Technology Handbook. Hansher Publisher, Munich, Vienna, New York. Jankowska, H., A. Swiatkowski and J. Dhoma, 1991. Active Carbon. Ellis Horwood Limited, England.

Morton., M., 1987. Rubber Technology $3^{\text {th }}$ edition, Van Nostrand Reinhold, New York.

Patel, A.C., W.A. Brown, 1985. Carbon Black Structure and Viscoelastic Properties of Rubber Compunds. A presented the Rubber division American Chemical Sosiaty, $127^{\text {th }}$ meeting Los Angeles, California April 23-26.

Shreve, R.N. and J.A.Brink, 1977. Chemical Process Industries. Mc. Graw Hill International Book Company London.

SNI 06-1542-1984.Kompon Ban Dalam Untuk Kendaraan Bermotor. 